\section{BA Institute of \\ YK Business Administration \\ TK \\ Karachi \\ Leadership and Ideas for Tomorrow}

Business Review

Volume 16 Issue 1 January-June 2021

$1-1-2021$

\title{
Role of government initiatives in shaping entrepreneurial intentions: A canonical correlation analysis
}

\author{
Ansar Waseem \\ University of Management \& Technology, Lahore \\ Yasir Rashid \\ University of Management \& Technology, Lahore \\ Ahmad Ahsan Akbar \\ University of South Asia, Lahore
}

Follow this and additional works at: https://ir.iba.edu.pk/businessreview

Part of the Business Administration, Management, and Operations Commons, Operations and Supply Chain Management Commons, and the Organizational Behavior and Theory Commons

\section{(c) (1)}

This work is licensed under a Creative Commons Attribution 4.0 International License.

\section{Recommended Citation}

Waseem, A., Rashid, Y., \& Akbar, A. A. (2021). Role of government initiatives in shaping entrepreneurial intentions: A canonical correlation analysis. Business Review, 16(1), 13-29. Retrieved from https://doi.org/ 10.54784/1990-6587.1325

This article is brought to you by iRepository for open access under the Creative Commons Attribution 4.0 License and is available at https://ir.iba.edu.pk/businessreview/vol16/iss1/6. For more information, please contact irepository@iba.edu.pk. 


\title{
Role of government initiatives in shaping entrepreneurial intentions: A canonical correlation analysis
}

\author{
Ansar Waseem • Yasir Rashid . \\ Ahmad Ahsan Akbar
}

\begin{abstract}
This study aims to identify a correlation between government initiatives and entrepreneurial perception using Global Entrepreneurship Monitor data. It uses the parameters of perceived opportunity, perceived capability, and entrepreneurial intention to correlate them with different government initiatives such as supportive and relevant policies, taxes related policies, government entrepreneurship programs, commercial and legal infrastructure, physical infrastructure and entrepreneurial education at the post-school stage. This multi-level framework is tested using canonical correlation analysis. Results validate our proposed conceptual framework by highlighting that government initiatives are significantly related to perception about opportunities, capabilities, and intention about entrepreneurship. The perception of capabilities and self-efficacy were the most important factors in gauging citizen's perception about entrepreneurship. Similarly, government policies regarding taxes and bureaucracy, entrepreneurial education at the post-school stage, and physical infrastructure were the most important government interventions in shaping entrepreneurial perceptions among its citizens.
\end{abstract}

Keywords Entrepreneurial perception - Government initiatives · Formal and informal institutions · Canonical correlation analysis

\section{Introduction}

Entrepreneurship has been widely accepted by research scholars as a driver of innovation and economic growth (Busenitz et al 2000; Ribeiro-Soriano and

Ansar Waseem

University of Management and Technology-Lahore

E-mail: ansarwasim436@gmail.com

Yasir Rashid

University of Management and Technology-Lahore

Ahmad Ahsan Akbar

University of South Asia-Lahore

(C)Waseem, A., Rashid, Y. and Ahmad, A. A. 2021 
Galindo-Martín 2012; Terjesen et al 2016; Van Stel et al 2005; Wennekers et al 2010). It is regarded as a potent way to boost productivity, competition, market efficiency as well as generating employment, poverty eradication, wealth creation, and regional development in a country (Phillips et al 2014; Rahim et al 2015; Robson et al 2009; Zhao et al 2005). This has encouraged governments around the world to formulate policies for promoting entrepreneurship. Such policies and actions can have a significant impact on business startups. According to Terjesen et al (2016), these policies are focused either on the demand side (by providing entrepreneurial opportunities) or on the supply side (by emphasizing on characteristics of potential entrepreneurs).

Government initiatives add legitimacy to entrepreneurship in a society by fostering a national entrepreneurial culture. This culture motivates individuals to start their businesses by creating a positive perception of entrepreneurship (Shinnar et al 2012). The development of formal and informal institutions that make business startup easier is another way to foster entrepreneurial activities. These institutions are the rule of games (North et al 1990) that influence human behavior (Liñán and Fayolle 2015). The economic, political, and legal systems of a country define the set of opportunities that are available to potential entrepreneurs (Murdock 2012). Similarly, regulatory institutions have a significant influence on the cost of business startups as they reduce the cost of production and transaction.

However, government initiatives to foster entrepreneurship will remain futile if the individuals are unable to identify new business opportunities. The level of motivation and self-efficacy of potential entrepreneurs is considered as crucial predictors in the creation of new business ventures. The potential entrepreneur must perceive the existence of an entrepreneurial opportunity, and possess the capabilities to exploit those opportunities (Shane and Venkataraman 2000). Venture capitalists and economic development institutions are frustrated by the self-perceived inability of the entrepreneurs to start their own business (Griffiths et al 2009). Therefore, in addition to government initiatives, a certain level of self-efficacy, perceived capability, and entrepreneurial intention is required.

Although, different policies are devised by governments to create a positive perception about entrepreneurship; little empirical evidence exists regarding actual benefits from such entrepreneurial policies in influencing entrepreneurial activities (Murdock 2012; Kwapisz 2019; Urbano et al 2019). Few previous research studies have been undertaken to investigate the role of macroeconomic variables such as government policies, regulatory institutions in augmenting individual perception of citizens of a country (Congregado et al 2012; Griffiths et al 2009; Pickernell et al 2013). But in most of the studies, only one or two government initiatives are considered. In their systematic literature review on entrepreneurial intention, Liñán and Fayolle (2015) have observed that perceived barriers to entrepreneurial intention are under-researched. Moreover, Zhao et al (2005) note that the study of factors that leads a person towards entrepreneurship is under-developed. The issue is equally important for policy-makers as well. For instance, Davari and Farokhmanesh (2017) point out Iranian policymakers are putting in efforts to assess the influence of entrepreneurship policies 
Role of government initiatives in shaping entrepreneurial intentions...

in new business creations.

This study aims to fulfill gap in the literature by investigating the role of macroeconomic variables such as government policies, tax laws, and other contextual circumstances such as entrepreneurial education and infrastructure in shaping the perception of people about entrepreneurship. Through this research, an important research question is addressed: in what way the government initiatives influence the perception of its people to start their own business? Instead of using a single aspect of government policies, this study considers several government initiatives that shape the perception of people towards entrepreneurship.

The current study focuses on identifying different government policies which boost entrepreneurial activities in the country. Following the study of Hlaváček et al (2015) institutional environment is described at the macro, meso, and micro level in this study. The macro-level pertains to government policies regarding entrepreneurship, the meso level covers financial, commercial, legal, and physical infrastructure, while the micro-level deals with the support extended to people in the form of entrepreneurial education. Therefore, six pertinent government initiatives i.e. supportive and relevant policies, taxes-related policies, government entrepreneurship programs, commercial and legal infrastructure, physical infrastructure, and entrepreneurial education at the post-school stage are chosen. Moreover, three different aspects i.e., perceived opportunity, perceived capability, and entrepreneurial intentions are used to measure the inclination of people to start their own business. Later on, a multi-level framework is proposed that shows how government initiative shapes the perception of people towards entrepreneurship. This multi-level framework is tested using canonical correlation analysis based on the data collected from Global Entrepreneurship Monitor (GEM) Report.

Results of the data analysis support the proposed conceptual framework. The perception of capabilities was found out to be the most important factor in determining citizen's perception about entrepreneurship. Likewise, government policies regarding taxes and bureaucracy, entrepreneurial education at post-school stage, and physical infrastructure were the most important government interventions in shaping entrepreneurial perceptions among its citizens. Although GEM database is extensively used in different entrepreneurship research papers; neither GEM report nor any empirical papers have investigated how a group of government interventions impact the intention of the people to start their own business. The intellectual and theoretical contribution of this paper lies in highlighting and explaining the correlation between government initiatives at a different level and the entrepreneurial intention of its citizens. Then, this paper analyzes and tests the proposed model using GEM data.

An important theoretical contribution of this study is the combination of institutional theory with a theory of planned behavior. Institutional theory is considered to be the best conceptual framework to explain entrepreneurship (Barinova et al 2018; Baughn et al 2006; Busenitz et al 2000; Chowdhury et al 2019; North et al 1990; Ribeiro-Soriano and Galindo-Martín 2012; Veciana 2007; Waseem 2018). Proponents of this theory suggest that social, economic, and political institutions have a significant role in the decision-making process of managers and entrepreneurs (Lee and Wong 2002). On the other hand, the theory 
of planned behavior postulates how an individual's perceptions and intentions can be influenced. Through the combination of these two theories, a multilevel framework for the current paper is proposed. This agrees with neoclassical theories of economics which intend to establish a link between entrepreneurship and macroeconomic variables (Minniti and Lévesque 2008). The proposed framework highlights how the institutional environment of a country stimulates entrepreneurial initiatives by affecting the perception and intention of people about entrepreneurship.

\section{Literature review}

2.1 Government initiatives to support entrepreneurship

In the era of globalization where forces applying from all around compel businesses to downsize and outsource their processes, the quest to find better alternative sources of organizations as well as economic growth is increasing. The creation of new ventures mostly by small and mid-size enterprises (SMEs) is a vital factor for the growth of the economy. Entrepreneurship has been regarded as a driving force for innovation that spurs economic development at a faster rate (Carree and Thurik 2008; Reynolds 1997; Schumpeter 1934). Entrepreneurial activities are considered an essential element for the economic development of a country and government policies play a vital role in supporting and promoting these activities.

Entrepreneurial policies are the ones that are formulated by the governments to promote entrepreneurship in a region or country (Stevenson and Lundström 2001). It entails developing policies that focus on both social and economic facets (Terjesen et al 2016). These policies can be divided into hard and soft policies. The hard policies emphasize financial support and soft policies pertain to the development of capabilities and skills among potential entrepreneurs (Robson et al 2009). Government policies to support entrepreneurship include macroeconomics, tax policies, legislation, regulatory bodies, influence on the marketrelated institution (Smallbone and Welter 2010), micro-credit schemes for SMEs (Cancino et al 2015), technology development and innovation programs, subsidized business advice for small firms (Congregado et al 2012) and establishment of licensing and registration offices (Nguyen et al 2009). Governments also devise policies to provide self-employment opportunities to unemployed people of the country (Hlaváček et al 2015).

Along with the development of entrepreneurial policies, governments also focus on developing institutions to provide support to both new and established businesses. According to Kostova (1997), the institutional profile of a country consists of three dimensions i.e., regulatory dimension, cognitive dimension, and normative dimension. The regulatory dimension entails institution, governmental policies, laws and regulation which extend support for the establishment of new businesses (Busenitz et al 2000; Murdock 2012). These legal, economic, and financial institutional pillars of a country cultivate superior quality entrepreneurial activities (Terjesen et al 2016). These include regulatory bodies, 
tax authorities, business registering offices, development agencies, and private institutions such as banks, financial institutions, accountants (Smallbone and Welter 2010). These institutions facilitate entrepreneurial firms in acquiring required resources to minimize the level of risk for new ventures as well as providing them support to grow further. It provides support by creating a mechanism that facilitates establishing new businesses with ease and protecting the investor's interest to reduce the potential risk.(Rondinelli and Kasarda 1992).

Focusing on the research of Shane and Venkataraman (2000), an individual should have prior information about the existence of opportunity and cognitive capabilities to exploit them. Here, entrepreneurial education can play a significant role. In the current era of rapid change, entrepreneurship education (EE) is becoming more pervasive (Solomon 2007). Entrepreneurial education is recognized by policy-makers as an efficient mechanism to foster entrepreneurship as it focuses on both identification of opportunities for entrepreneurship and taking suitable action (Terjesen et al 2016). It is different from conventional education as it develops skills and knowledge necessary for successful business (Verheul et al., 2001), thereby influencing entrepreneurial behaviors and tendencies (O'Connor 2013). Scholars believe that entrepreneurial education should be approached differently than traditional education. Entrepreneurial education becomes more effective when it is associated with entrepreneurial training, experiential and action learning (Rahim et al 2015).

\subsection{Entrepreneurial intention}

Previous research on entrepreneurial intention has viewed it from the social psychology perspective which highlights on analyzing general behaviors associated with entrepreneurship (Liñán and Fayolle 2015). It is regarded as the behavioral pattern related to the initiatives taken by the individuals on self-starting approach to overcome the setbacks and barriers (Frese et al, 1996). The approach of self-starting refers to the proactive nature of an individual who is self-motivated to set goals and accomplish tasks without supervision. Avoiding potential problems that could arise during the business operations and anticipating upcoming future requirements are the main aims for these initiatives. Fay and Frese (2001) have found some key environmental supporting factors, such as control at work, stressors, and support for personal initiatives, influencing the individual to take personal initiatives.

Lüthje and Franke (2003) have found that the entrepreneurial intention of engineering students at MIT is directly associated with perceived barriers and support to entrepreneurs. This means that these two variables can be used in conjunction with perceived capabilities to estimate the entrepreneurial intentions of citizens in a country. The decision to start a new business depends upon the perceived opportunities of entrepreneurship as well as the level of selfefficacy of the potential entrepreneur. Only a person having a good perception of self-abilities can seize a business opportunity. 


\section{Conceptual framework}

The literature on entrepreneurship has either focused on individual related factors or on the contextual environment. However, the study of entrepreneurship should include opportunities and their sources, as well as individuals who identify and exploit these opportunities (Shane and Venkataraman 2000). This study extends the existing literature by considering both these aspects of opportunities simultaneously. Infrastructural support from the government provides ground for individuals to follow entrepreneurial activities. Through dedicated entrepreneurial policies, supportive institutions, and developed physical infrastructures, governments attempt to create a positive perception about entrepreneurship.

Entrepreneurial opportunities are defined as 'those situations in which new goods, services, raw materials, and organizing methods can be introduced and sold at greater than their cost of production' (Shane and Venkataraman 2000). Governments try to create more opportunities for entrepreneurs to boost the economic growth. The importance of nascent business in economic growth has encouraged governments to develop macro-level policies and a comprehensive institutional system to support new business creation (Lee and Wong 2002). Governments focus on the development of macro-economic policies regarding taxation and entrepreneurial programs. One part of these policies is the development of formal institutions which facilitate new business start-up by reducing business setup, transaction, and production costs. On the other hand, they develop informal institutions that add legitimacy to entrepreneurship by affecting values, norms, and culture in the society. Governments focus on the demand side by creating more business opportunities for the citizens. Government initiatives coupled with formal and informal institutions formulate the rules of business and modify the perception of entrepreneurs. Policies related to education, tax, legislation, and regulatory bodies affect the process and outcome of new business creation (Ribeiro-Soriano and Galindo-Martín 2012). All these interventions develop a positive perception regarding the existence of an opportunity among people and encourage them to start a new business venture.

Government activities to support opportunity-based self-employment can-

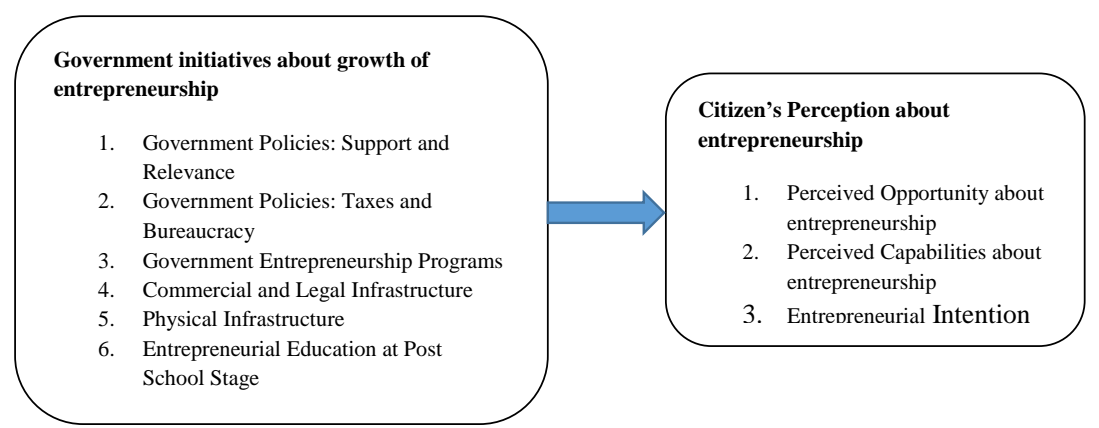

Fig. 1: Impact of government initiatives on perception of entrepreneurship 
not be limited to one level. At the macro-level government policies and entrepreneurship programs are considered; while legal, commercial, and physical infrastructure pertains to meso-level. Lastly, support extended to citizens in the form of entrepreneurial education falls at the micro-level. Therefore, a multilevel approach is more suitable to study government interventions to create a positive perception among its citizen about entrepreneurship. Based on the above argument, we present our framework in figure 1.

\section{Data and methodology}

For this study data was collected from Global Entrepreneurship Monitor (GEM) Report 2016-17 which gauges entrepreneurial activities in a country by assembling data on an annual basis (Hattab 2012). Global Entrepreneurship Monitor measures the perception of individuals of a country towards entrepreneurship by measuring their perception of opportunities, perception of capabilities, and motivation to enter in entrepreneurship. These measures were selected based on the previous researchers. For instance, Liñán et al (2011) have focused on the perception of people about entrepreneurship. Authors such Liñán and Fayolle (2015) believe that self-efficacy and perception about one's belief is an important antecedent of entrepreneurial intention. Taking support from this, the current study is using perceived opportunity about entrepreneurship, perceived capabilities about entrepreneurship, and entrepreneurial intention to represent citizen's perceptions about entrepreneurship.

Similarly, GEM Report for 2016-17 was also used to collect data from 64 countries about different government initiatives to foster entrepreneurship. These measures are taken under National Expert Survey to capture the perception of experts of a country about the factors which can foster or constrain the growth of entrepreneurship in their countries. Previous researchers have adopted different measures to represent government initiatives for promoting entrepreneurship. For example, Djankov et al (2002) have focused on government policies, while Hlaváček et al (2015) have considered institutional barriers, public institutions and legal environment. Nguyen et al (2009), in their study, have identified legal and administrative reforms, taxation policy, finance and credit policy, trade and export promotion policies, technology and information, training and development and land policy as important factors which support the growth of newly created SMEs. Barinova et al (2018) point out that the extant entrepreneurship literature has emphasized government policies, legal environment and tax regulations as important institutional factors. Following these studies, government policies regarding support to entrepreneurs, policies about taxation, government-sponsored entrepreneurial programs, physical and commercial infrastructure, and entrepreneurial education were chosen as the measures to capture government initiatives regarding the growth of entrepreneurship.

To test the proposed framework, Canonical Analysis was used. This method allows checking association between multiple metric/non-metric dependent variables and two or more nominal and interval independent variables (Darlington et al 1973; Hair et al 1998) by maximizing the correlation between the two. To 
the best of the author's knowledge, the previous studies have focused on only a few factors i.e. either one government initiative was focused on or the multiple regression model considered only one factor of entrepreneurial intention as the DV. However, the current study simultaneously considers a number of factors regarding government initiatives and entrepreneurial orientation and attempts to study their correlation. As the main purpose of this paper is to investigate the impact of a set of government initiatives on the growth of entrepreneurial intentions among its citizen, canonical correlation analysis was consistent with the aim of the study (Mahmood and Mann 1993).

For this study, our canonical variates (consisting of a set of dependent and independent variables) are given as under:

$$
\begin{aligned}
& \text { Independent Variate : } U=a_{1}(\text { government policies regarding support to entrepreneurs }) \\
& \begin{array}{r}
+a_{2}(\text { policies about taxation })+a_{3}(\text { government entrepreneurial programs }) \\
+a_{4}(\text { commercial and legal infrastructure })+a_{5} \\
(\text { physical infrastructure })+a_{6}(\text { entrepreneurial education })
\end{array}
\end{aligned}
$$

$$
\begin{aligned}
& \text { Dependent Variate }: V=b_{1}(\text { opportunity about entrepreneurship })+b_{2} \\
& \text { (perceived capabilities about entrepreneurship })+b_{3}(\text { entrepreneurial intention })
\end{aligned}
$$

\section{Results}

Before performing actual data analysis, necessary conditions for canonical relationships were first fulfilled. Hair et al (1998) recommend that conditions of linearity, normality, multi-colinearity, and homoscedasticity should be fulfilled before performing canonical analysis. It is assumed that both canonical variates are linearly related to each other.

To detect the presence of outliers and influential values in the data set, both standardized residuals and leverage values were calculated. Standardized Residual for each independent variable with all dependent variables was calculated. In all three regression models, no value of the standardized residual is found to be greater than 3 in absolute value. This means that there is no outlier in the data (Mendenhall et al 1996). Similar results are obtained from the leverage value as in all cases the calculated leverage value of each observation was above the average leverage value of all observations.

Afterward, the normality of the data was checked. For this purpose, the Shapiro Wilk test was used. For this test, the Null Hypothesis is that the residual has a normal distribution (Mendenhall et al 1996). In two cases, this null hypothesis was accepted while in one case it was rejected. However, this test is of limited use in actual practice because mostly the null hypothesis is accepted (Mendenhall et al 1996). Afterward, autocorrelation between observations was checked. For six predictors and 64 sample size, the upper value of Durbin Watson $\left(d_{u}\right)$ is 1.603 at a $1 \%$ confidence interval. According to Gujrati and Porter 
(2013), the null hypothesis regarding no autocorrelation (positive or negative) cannot be rejected if $-d_{u}<d<4 d_{u}$. In all cases, the calculated value of $\mathrm{d}$ falls between 1.603 and 2.397. Therefore, we cannot reject our null hypothesis that there is no autocorrelation in the data.

Multi-colinearity between the independent variables was checked using Variance Inflation Factor (VIF). According to this criterion, multi-collinearity is present if the value of VIF is greater than 10 (Mendenhall et al 1996). None of the values of VIF was greater than 10 in our case which means no multicollinearity is present between the variables. Table 1 presents the descriptive statistics of the variables involved in the study. Mean, standard deviation, and range for different measures of government initiatives for growth of entrepreneurship and perception of citizens towards entrepreneurship were calculated. Among the measures considered to represent the citizen's perception about entrepreneurship, perceived capability had the highest mean value. Similarly, Physical Infrastructures was the most focused government intervention to spur new business creation.

Afterwards, measures of perception of citizens towards entrepreneurship were

Table 1: Descriptive statistics

\begin{tabular}{lccccc}
\hline Variables & Range & Min & Max & Mean & Std. Dev \\
\hline Perceived Opportunity & 68.50 & 13.00 & 81.50 & 42.217 & 14.420 \\
Perceived Capability & 59.40 & 25.20 & 84.60 & 50.325 & 13.395 \\
Entrepreneurial Intention & 61.70 & 2.10 & 63.80 & 22.328 & 14.503 \\
Government Policies: Support and Relevance & 3.30 & 2.60 & 5.90 & 4.194 & 0.886 \\
Government Policies: Taxes and Bureaucracy & 5.10 & 2.00 & 7.10 & 3.922 & 1.099 \\
Government Entrepreneurship Programs & 4.10 & 2.20 & 6.30 & 4.291 & 0.908 \\
Commercial and Legal Infrastructure & 2.40 & 3.70 & 6.10 & 4.938 & 0.543 \\
Physical infrastructures & 4.60 & 3.70 & 8.30 & 6.470 & 0.873 \\
Entrepreneurial Education at Post School Stage & 2.90 & 3.00 & 5.90 & 4.613 & 0.683 \\
\hline
\end{tabular}

correlated with themselves. The result is given in table 2. All the measures have significant and positive correlation with one another. A stronger correlation was observed between perceived capabilities and entrepreneurial intentions which resonate with the claim of Zhao et al (2005) that self-efficacy is regarded as an important antecedent of entrepreneurial intention.

Similarly, table 3 shows the correlation between different measures of govern-

Table 2: Correlation between perception of citizens towards entrepreneurship

\begin{tabular}{lccc}
\hline Variables & 1 & 2 & 3 \\
\hline Perceived Opportunity & 1 & & \\
Perceived Capability & $0.435^{* * *}$ & 1 & \\
Entrepreneurial Intention & $0.392^{* * *}$ & $0.705^{* * *}$ & 1 \\
\hline$* * * \mathrm{p}<0.01,{ }^{* *} \mathrm{p}<0.05,{ }^{*} \mathrm{p}<0.1$, & &
\end{tabular}

ment initiatives to support and boost entrepreneurship in a country. Here again all the measures are positively and significantly related to one and another.

Business Review: (2021) 16(1):13-29 
This shows that these measures reinforce each other in creating a supportive entrepreneurial environment in the country.

Canonical correlation analysis was employed for testing the proposed frame-

Table 3: Correlation between government initiatives for entrepreneurship

\begin{tabular}{|c|c|c|c|c|c|c|}
\hline Variables & 1 & 2 & 3 & 4 & 5 & 6 \\
\hline $\begin{array}{l}\text { Gov Policies: Support and Rel- } \\
\text { evance }\end{array}$ & 1 & & & & & \\
\hline $\begin{array}{l}\text { Gov Policies: Taxes and Bu- } \\
\text { reaucracy }\end{array}$ & $0.595^{* * *}$ & 1 & & & & \\
\hline $\begin{array}{l}\text { Gov Entrepreneurship Pro- } \\
\text { grams }\end{array}$ & $0.683^{* * *}$ & $0.598^{* * *}$ & 1 & & & \\
\hline $\begin{array}{l}\text { Commercial and Legal Infras- } \\
\text { tructure }\end{array}$ & $0.267^{* *}$ & $0.292^{* *}$ & $0.433^{* * *}$ & 1 & & \\
\hline Physical infrastructure & $0.301^{* *}$ & $0.504^{* * *}$ & $0.384^{* * *}$ & $0.365^{* * *}$ & 1 & \\
\hline $\begin{array}{l}\text { Entrepreneurial Education at } \\
\text { Post School Stage }\end{array}$ & $0.402^{* * *}$ & $0.290^{* *}$ & $0.447^{* * *}$ & $0.266^{* *}$ & 0.124 & 1 \\
\hline
\end{tabular}

work as it gives ideas regarding whether or not the set of dependent and independent variables are related in a linear sense. It also provides the magnitude of the correlation between these canonical variates (Mahmood and Mann 1993). Therefore, our null and alternate hypotheses are as under:

Null Hypothesis: There is no significant correlation between any pair of canonical variates.

$\rho\left(U_{1}, V_{1}\right)=\rho\left(U_{2}, V_{2}\right)=\rho\left(U_{3}, V_{3}\right)=0$

Alternative Hypothesis: There is a significant correlation between at least one pair of canonical variates.

Different tests can be used to check whether both sets of predictor and outcome variables are significantly related or otherwise. These include Pillai's Test, Hotelling Test, and Wilks Test. Table 4 shows the results of these statistics. All these tests are statistically significant at a $p-$ value $<0.05$. This shows that both canonical variates are statistically related to each other.

The reason for such a significant relationship is that the canonical regres-

Table 4: Multivariate tests of significance

\begin{tabular}{lccc}
\hline Test & Val of stats & App F-values & Sig of F-stat \\
\hline Pillais & 0.465 & 1.743 & 0.036 \\
Hotelling & 0.584 & 1.757 & 0.035 \\
Wilks & 0.593 & 1.757 & 0.035 \\
\hline
\end{tabular}

sion analysis considers all dependent and independent variables simultaneously (Mahmood and Mann 1993). Consequently, these results provide a combined effect of measures of different government initiatives to support entrepreneurship on measures of perception of people towards entrepreneurship. This combined effect is usually stronger than the individual effect of variables (Mahmood and Mann 1993). 
Role of government initiatives in shaping entrepreneurial intentions...

This strengthens the notion that governmental policies along with economic and legal institutions shape the perception of citizens of a country towards entrepreneurship (Murdock 2012). They also affect entrepreneurial behaviors by determining incentives available to entrepreneurs on starting their own business. Countries with better tax and bankruptcy laws, fewer procedures, and short time required to start a business have better entrepreneurship rates (Terjesen et al 2016). Western countries can be quoted as a good example where supportive formal institutions have accelerated economic progress through the development of business enterprises. Poor entrepreneurial policies, on the other hand, force entrepreneurs to start a business in low growth sectors which have a minimal economic impact. Djankov et al (2002) have found that restrictive entrepreneurial policies result in a lower rate of entry of firms. Similarly, Hlaváček et al (2015) revealed that institutional barriers, public administration and legislative environment have a significant impact on the growth of entrepreneurial initiatives.

However, the canonical analysis can be extended to determine which canonical function is more suitable. The maximum number of canonical functions that can be derived depends upon the number of variables in the smaller set (Hair et al 1998). In this case, the smaller set contains 3 variables; therefore, there are only three sets of canonical functions. The first canonical function explains the maximum amount of variance between both sets of variables (Hair et al 1998). The second one, being orthogonal to the other ones, explains the variation between the two variates not accounted for by the first canonical function. Afterward, we check the significance level of these canonical functions. According to Stewart and Love (1968), the level of significance decides which canonical function should be included in the analysis. Table 5 demonstrates that among three canonical functions only the first one is statistically significant. Furthermore, this function explains maximum variation between both sets of the dependent and independent variables. This means that this canonical function explains around $23 \%$ variation between the two canonical variates.

However, relying only on canonical correlation provides an insufficient expla-

Table 5: Measuring overall model fit for canonical correlation analysis

\begin{tabular}{ccccc}
\hline Function No & Canonical Corr & Canonical $R^{2}$ & F-Stat & Sig Val \\
\hline 1 & 0.482 & 0.232 & 1.757 & 0.035 \\
2 & 0.454 & 0.206 & 1.542 & 0.134 \\
3 & 0.164 & 0.027 & 0.396 & 0.811 \\
\hline
\end{tabular}

nation as it does not pay attention to canonical loading (Van Den Wollenberg, 1977). For this purpose, the redundancy index is used which is described as the ability of independent variables (e.g. government initiatives about entrepreneurship), taken together as a set, to explain variation in the dependent variables taken independently (e.g. perception of citizens about entrepreneurship). The redundancy index is non-symmetrical (Van Den Wollenberg, 1977) which means that unlike canonical correlation values of redundancy index are different. But, since researchers are more interested in studying variation between the depen-

Business Review: (2021) 16(1):13-29 
A. Waseem et. al

dent variables, it is common practice to explain redundancy index only for dependent variables (Hair et al 1998; Mahmood and Mann 1993).

Table 6 shows the calculation of the redundancy index for only significant

Table 6: Canonical redundancy analysis for significant canonical function

\begin{tabular}{lccccc}
\hline Variates & $\begin{array}{l}\text { Canonical } \\
\text { Loading }\end{array}$ & $\begin{array}{l}\text { Square of } \\
\text { Canonical } \\
\text { Loading }\end{array}$ & $\begin{array}{l}\text { Avg of } \\
\text { Square }\end{array}$ & $\begin{array}{l}\text { Canonical } \\
R^{2}\end{array}$ & $\begin{array}{l}\text { Redundancy } \\
\text { Index }\end{array}$ \\
\hline $\begin{array}{l}\text { Perceived Op- } \\
\text { portunity }\end{array}$ & 0.083 & 0.007 & & & \\
$\begin{array}{l}\text { Perceived Capa- } \\
\text { bility }\end{array}$ & -0.784 & 0.614 & 0.366 & 0.232 & 0.085 \\
$\begin{array}{l}\text { Entrepreneurial } \\
\text { Intention }\end{array}$ & -0.691 & 0.477 & & & \\
\hline
\end{tabular}

canonical function i.e. first canonical function. To ascertain the variation explained by the function, total redundancy for all three canonical functions was calculated. Results given in table 7 show that three canonical functions have total redundancy of $15.88 \%$. This means that nearly $16 \%$ variation in the individual dependent variable is explained by the independent variate. Out of this nearly $53.5 \%$ variation is explained by the first canonical function. Although, the second canonical function shares $41 \%$ in total redundancy, the same is statistically insignificant. The last function has an explanatory portion of just $5 \%$ which is very low and practically irrelevant. In our case, since only the first function is statistically significant, therefore, only results of this function are interpreted further.

Following Hair et al (1998), canonical loading or canonical structure cor-

Table 7: Portion of total redundancy attributable to each canonical function (in \%)

\begin{tabular}{lcccc}
\hline $\begin{array}{l}\text { Canonical } \\
\text { Function }\end{array}$ & $\begin{array}{l}\text { Avg of Square } \\
\text { Canonical Loading }\end{array}$ & $\begin{array}{l}\text { Canonical } \\
R^{2}\end{array}$ & $\begin{array}{l}\text { Redundancy } \\
\text { Index }\end{array}$ & $\begin{array}{l}\text { Portion of total } \\
\text { redundancy in \% }\end{array}$ \\
\hline 1 & 0.366 & 0.232 & 0.085 & 53.530 \\
2 & 0.317 & 0.206 & 0.065 & 41.060 \\
3 & 0.318 & 0.027 & 0.009 & 5.410 \\
& & & 0.159 & 100.000 \\
\hline
\end{tabular}

relations are used which are simple linear correlations between the variable in a given set (either dependent or independent) and its corresponding canonical variate. This measure was chosen to avoid the inherent deficiencies in the canonical weights. The rank order of the importance of the variable is done based on the absolute value of canonical loadings. Table 8 gives the canonical loadings for the dependent variable in the first function. In terms of absolute values of canonical loadings, the perceived capability of entrepreneurs is the most important variable in the dependent variate followed by entrepreneurial intention. This shows the importance of the abilities and self-efficacy of the entrepreneur in starting their own business. 
Role of government initiatives in shaping entrepreneurial intentions...

Entrepreneurial education positively modifies the attitude of potential entrepreneurs by enhancing their perception of opportunities and decreasing fear of failure (Farashah 2013). Entrepreneurial education gives self-confidence to people which stimulates them to start their own business. Cheung (2008) noted that entrepreneurial education programs conducted in Hong Kong at the secondary school level were successful in creating awareness among students about developing personal and business-related skills. Sexton and Moore (1995) reported that among those students which attended entrepreneurial education, $40 \%$ end up starting their own business. Similarly, Farashah (2013) has determined that one course related to entrepreneurship increases entrepreneurial intention by 1.3 times.

Similarly, among the independent variables government policies regarding

Table 8: Canonical loadings for dependent variate

\begin{tabular}{lc}
\hline Variates & $\begin{array}{c}\text { Canonical Loading } \\
\text { Function I }\end{array}$ \\
\hline Perceived Opportunity & 0.083 \\
Perceived Capability & -0.784 \\
Entrepreneurial Intention & -0.691 \\
\hline
\end{tabular}

taxes and bureaucracy, entrepreneurial education at a post-school stage, and physical infrastructure were the first, second, and third highest variables in determining the government initiatives regarding the growth of entrepreneurship. This shows the importance of the development of formal institutions in supporting entrepreneurial initiatives in the country.

Table 9: Canonical loadings for independent variate

\begin{tabular}{lc}
\hline Variates & $\begin{array}{c}\text { Canonical Loading } \\
\text { Function I }\end{array}$ \\
\hline Government Policies: Support and Relevance & 0.545 \\
Government Policies: Taxes and Bureaucracy & 0.806 \\
Government Entrepreneurship Programs & 0.641 \\
Commercial and Legal Infrastructure & 0.174 \\
Physical infrastructures & 0.710 \\
Entrepreneurial Education at Post School Stage & 0.751 \\
\hline
\end{tabular}

\section{Discussion}

Governments are paying special attention to developing policies and institutions beneficial for entrepreneurship. However, the actual outcome of such initiatives is relatively unknown. This paper attempts to bridge the gap in the extant literature by proposing a framework that shows the effect of a set of government initiatives in promoting different facets of entrepreneurial intention among its citizen. This was supported by the result of the data obtained from the GEM 
database using canonical correlation analysis. Using canonical analysis, it has been demonstrated that entrepreneurial policies foster entrepreneurial activities in a country by depicting it as a positive activity. Our results also resonate with previous research. For example, in their comparative study of social valuation of entrepreneurship in Catalonia and Andulsia, Liñán et al (2011) have found that citizens of the developed region have a positive perception of entrepreneurship. Kosa and Mohammed (2017) have determined that human and financial capital coupled with government supports strengthens new business creation. Findings of a study conducted by Chowdhury et al (2019) suggest that institutions play a vital role in the quality as well as quantity of entrepreneurial activities.

Results of the current paper show the importance of formal institutions in promoting entrepreneurial activities in a country. It is well established that entrepreneurs face a shortage of resources. Government, being a central stakeholder in entrepreneurship, should provide indispensable resources and formal support to new business initiatives in a cost-effective way. Supportive institutions result in lower transaction costs and they play a pivotal role in the growth of new business startups (Smallbone and Welter 2010).

Smékalová et al (2014) emphasize that governments can play a bigger role since it can influence the perception of people. The way government promotes entrepreneurship in a country provides the normative support that engaging in entrepreneurship is socially acceptable behavior. The government can develop an entrepreneurial ecosystem and culture in a region or country which will attract people to engage in entrepreneurship. On one hand, governments can reduce the effects of information asymmetry disadvantage for new entrepreneurs; while on the other they can create positive spillover from existing economic activities. For this purpose, entrepreneurial policies and public institutions should be developed for providing better support to potential entrepreneurs (Hlaváček et al 2015).

This study supports the importance of entrepreneurial education in developing entrepreneurial intentions. Entrepreneurial education can be used to leverage government initiatives by creating positive perceptions about entrepreneurial opportunities and capabilities (Minniti and Lévesque 2008). Entrepreneurial education improved perception of opportunity through the development of selfefficacy. For instance, the Malaysian Ministry of Higher Education has declared entrepreneurship-related subjects compulsory at national universities (Rahim et al 2015). Such programs will develop human capital and entrepreneurs will be able to exploit business opportunities.

\section{Conclusion}

This study has proposed a multi-level framework describing how different government initiatives shape the perception of people about opportunities, capabilities, and intentions about entrepreneurship. This research focused on the parameters of perceived opportunity, perceived capability, and entrepreneurial intention to correlate them different government initiatives such as supportive and relevant policies, taxes related policies, government entrepreneurship 
programs, commercial and legal infrastructure, physical infrastructure, and entrepreneurial education at the post-school stage. This multi-level framework was tested by collecting data from Global Entrepreneurship Monitor which was later analyzed through Canonical Correlation Analysis. Results indicate that set of different measures of government initiatives to promote entrepreneurship is significantly related to a set of variables measuring the perception of citizens about entrepreneurship. Among government initiatives, policies regarding taxes and bureaucracy, entrepreneurial education, and physical infrastructure were the most important; whereas perceived capabilities and self-efficacy is the most important variable in describing the perception of people regarding entrepreneurship.

An important theoretical contribution of this study is the combination of certain aspects of institutional theory and the theory of planned behavior. Both these theories involve different units of analysis, but this paper combines these two different perspectives by demonstrating how the institutional environment of a country stimulates entrepreneurial initiatives by affecting the perception and intention of people towards entrepreneurship. Based on the results of this study, the government can identify and adopt different policies that promote new business ventures by influencing the perception and intention of people regarding entrepreneurship.

\section{Limitations and future research directions}

A major limitation of this study is the use of cross-sectional data. A more extensive study should consider time-series data as an outcome of government policies that are visible in long run (Congregado et al 2012). Another limitation of this study is the smaller sample size. Hair et al (1998) recommends that there should be at least 10 observations per variable. However, in our case, this criterion was not fulfilled as the available data in the GEM Report for the Year 2016-17 had data for only 64 countries.

Further, studies can test the proposed framework by considering longitudinal data. Moreover, data of a particular country or region can be used to validate our findings. Other measures for government initiatives or perceptions of citizens can be added in the framework to add robustness. The framework can be extended by investigating the combined effect of institutional environment and perception of people towards entrepreneurship in enhancing the economic growth of a country.

\section{References}

Barinova VA, Zemtsov SP, Tsareva YV, et al (2018) Entrepreneurship and institutions: Does the relationship exist at the regional level in russia. Voprosy Ekonomiki 6:92-116

Baughn CC, Chua BL, Neupert KE (2006) The normative context for women's participation in entrepreneruship: A multicountry study. Entrepreneurship theory and practice 30(5):687708

Busenitz LW, Gomez C, Spencer JW (2000) Country institutional profiles: Unlocking entrepreneurial phenomena. Academy of Management journal 43(5):994-1003

Business Review: (2021) 16(1):13-29 
A. Waseem et. al

Cancino CA, Bonilla CA, Vergara M (2015) The impact of government support programs for the development of businesses in chile. Management Decision

Carree MA, Thurik AR (2008) The lag structure of the impact of business ownership on economic performance in oecd countries. Small business economics 30(1):101-110

Cheung CK (2008) Entrepreneurship education in hong kong's secondary curriculum. Education+ Training

Chowdhury F, Audretsch DB, Belitski M (2019) Institutions and entrepreneurship quality. Entrepreneurship Theory and Practice 43(1):51-81

Congregado E, Golpe AA, Parker SC (2012) The dynamics of entrepreneurship: hysteresis, business cycles and government policy. Empirical Economics 43(3):1239-1261

Darlington RB, Weinberg SL, Walberg HJ (1973) Canonical variate analysis and related techniques. Review of Educational Research 43(4):433-454

Davari A, Farokhmanesh T (2017) Impact of entrepreneurship policies on opportunity to startup. Management Science Letters 7(9):431-438

Djankov S, La Porta R, Lopez-de Silanes F, Shleifer A (2002) The regulation of entry. The quarterly Journal of economics 117(1):1-37

Farashah AD (2013) The process of impact of entrepreneurship education and training on entrepreneurship perception and intention: Study of educational system of iran. Education+ Training 55(8-9):868-885

Fay D, Frese M (2001) The concept of personal initiative: An overview of validity studies. Human performance 14(1):97-124

Griffiths MD, Kickul J, Carsrud AL (2009) Government bureaucracy, transactional impediments, and entrepreneurial intentions. International small business journal 27(5):626-645

Hair J, Anderson R, TATHAM RYB, Black W (1998) Wc (1998). multivariate data analysis. Englewood Cliffs

Hattab H (2012) Towards understanding female entrepreneurship in middle eastern and north african countries: A cross-country comparison of female entrepreneurship. Education, business and society: Contemporary Middle Eastern issues

Hlaváček P, Zambochova M, Sivicek T (2015) The influence of the institutions on entrepreneurship development: Public support and perception of entrepreneurship development in the czech republic. Amfiteatru Economic Journal 17(38):408-421

Kosa A, Mohammed I (2017) Uncovering the backings to passion: why do small firm owners/managers engage in entrepreneurship? Journal of Innovation and Entrepreneurship $6(1): 1-13$

Kostova T (1997) Country institutional profiles: Concept and measurement. In: Academy of management proceedings, Academy of Management Briarcliff Manor, NY 10510, vol 1997, pp $180-184$

Kwapisz A (2019) Do government and legal barriers impede entrepreneurship in the us? an exploratory study of perceived vs. actual barriers. Journal of Business Venturing Insights 11:e00,114

Lee L, Wong PK (2002) Cognitive divergence among entrepreneurship national experts: Analysis of gem data 2000-2003. In: Babson College, Babson Kauffman Entrepreneurship Research Conference (BKERC), vol 2006

Liñán F, Fayolle A (2015) A systematic literature review on entrepreneurial intentions: citation, thematic analyses, and research agenda. International Entrepreneurship and Management Journal 11(4):907-933

Liñán F, Urbano D, Guerrero M (2011) Regional variations in entrepreneurial cognitions: Start-up intentions of university students in spain. Entrepreneurship and Regional Development 23(3-4):187-215

Lüthje C, Franke N (2003) The makingof an entrepreneur: testing a model of entrepreneurial intent among engineering students at mit. R\&d Management 33(2):135-147

Mahmood MA, Mann GJ (1993) Measuring the organizational impact of information technology investment: an exploratory study. Journal of management information systems 10(1):97-122

Mendenhall W, Sincich T, Boudreau NS (1996) A second course in statistics: regression analysis, vol 5. Prentice Hall Upper Saddle River, NJ

Minniti M, Lévesque M (2008) Recent developments in the economics of entrepreneurship

Murdock KA (2012) Entrepreneurship policy: Trade-offs and impact in the eu. Entrepreneurship \& Regional Development 24(9-10):879-893 
Role of government initiatives in shaping entrepreneurial intentions...

Nguyen TH, Alam Q, Perry M, Prajogo D (2009) The entrepreneurial role of the state and sme growth in vietnam. Journal of Administration and Governance 4(1):60-71

North DC, et al (1990) Institutions, institutional change and economic performance. Cambridge university press

O'Connor A (2013) A conceptual framework for entrepreneurship education policy: Meeting government and economic purposes. Journal of business venturing 28(4):546-563

Phillips M, Moos M, Nieman G (2014) The impact of government support initiatives on the growth of female businesses in tshwane south africa. Mediterranean Journal of Social Sciences 5(15):85-85

Pickernell D, Senyard J, Jones P, Packham G, Ramsey E (2013) New and young firms: Entrepreneurship policy and the role of government-evidence from the federation of small businesses survey. Journal of Small Business and Enterprise Development

Rahim HL, Kadir MABA, Abidin ZZ, Junid J, Kamaruddin LM, Lajin NFM, Buyong SZ, Bakri AA (2015) Entrepreneurship education in malaysia: A critical review. Journal of Technology Management and Business 2(2)

Reynolds PD (1997) New and small firms in expanding markets. Small business economics 9(1):79-84

Ribeiro-Soriano D, Galindo-Martín MÁ (2012) Government policies to support entrepreneurship. Entrepreneurship \& Regional Development 24(9-10):861-864

Robson PJ, Wijbenga F, Parker SC (2009) Entrepreneurship and policy: Challenges and directions for future research. International Small Business Journal 27(5):531-535

Rondinelli DA, Kasarda JD (1992) Foreign trade potential, small enterprise development and job creation in developing countries. Small Business Economics 4(4):253-265

Schumpeter J (1934) the theory of economic development, tr. By Redvers Opie, Harvard Economic Studies 40:20

Shane S, Venkataraman S (2000) The promise of entrepreneurship as a field of research. Academy of management review 25(1):217-226

Shinnar RS, Giacomin O, Janssen F (2012) Entrepreneurial perceptions and intentions: The role of gender and culture. Entrepreneurship Theory and practice 36(3):465-493

Smallbone D, Welter F (2010) Entrepreneurship and government policy in former soviet republics: Belarus and estonia compared. Environment and Planning C: Government and Policy 28(2):195-210

Smékalová L, Hájek O, Belás J, Macháček J (2014) Perception of small and medium entrepreneurship in the czech republic. Journal of Competitiveness

Solomon G (2007) An examination of entrepreneurship education in the united states. Journal of small business and enterprise development

Stevenson L, Lundström A (2001) Patterns and trends in entrepreneurship/SME policy and practice in ten economies, vol 3. Elanders Gotab Vällingby, Sweden

Stewart D, Love W (1968) A general canonical correlation index. Psychological bulletin $70(3 \mathrm{p} 1): 160$

Terjesen S, Bosma N, Stam E (2016) Advancing public policy for high-growth, female, and social entrepreneurs. Public Administration Review 76(2):230-239

Urbano D, Aparicio S, Audretsch D (2019) Twenty-five years of research on institutions, entrepreneurship, and economic growth: what has been learned? Small Business Economics 53(1):21-49

Van Stel A, Carree M, Thurik R (2005) The effect of entrepreneurial activity on national economic growth. Small business economics 24(3):311-321

Veciana JM (2007) Entrepreneurship as a scientific research programme. In: Entrepreneurship, Springer, pp 23-71

Waseem A (2018) Female entrepreneurship and economic growth: An institutional theory analysis. Pakistan Journal of Gender Studies 16:15-36

Wennekers S, Van Stel A, Carree M, Thurik R (2010) The relationship between entrepreneurship and economic development: Is it U-shaped? Now Publishers Inc

Zhao H, Seibert SE, Hills GE (2005) The mediating role of self-efficacy in the development of entrepreneurial intentions. Journal of applied psychology 90(6):1265 